\title{
Miranda
}

Revue pluridisciplinaire du monde anglophone /

Multidisciplinary peer-reviewed journal on the English-

speaking world

$6 \mid 2012$

Marking the Land in North America

\section{Samuel J. M. Alberti, Morbid Curiosities: Medical Museums in Nineteenth-Century Britain}

Laurence Talairach-Vielmas

\section{OpenEdition}

\section{Journals}

Electronic version

URL: http://journals.openedition.org/miranda/3078

DOI: 10.4000/miranda.3078

ISSN: 2108-6559

Publisher

Université Toulouse - Jean Jaurès

\section{Electronic reference}

Laurence Talairach-Vielmas, "Samuel J. M. Alberti, Morbid Curiosities: Medical Museums in Nineteenth-

Century Britain", Miranda [Online], 6 | 2012, Online since 28 June 2012, connection on 16 February 2021 URL: http://journals.openedition.org/miranda/3078; DOI: https://doi.org/10.4000/miranda.3078

This text was automatically generated on 16 February 2021.

\section{(c) $(1) \Theta \Theta$}

Miranda is licensed under a Creative Commons Attribution-NonCommercial-NoDerivatives 4.0 International License. 


\title{
Samuel J. M. Alberti, Morbid Curiosities: Medical Museums in Nineteenth-Century Britain
}

\author{
Laurence Talairach-Vielmas
}

\section{REFERENCES}

Samuel J. M. Alberti, Morbid Curiosities: Medical Museums in Nineteenth-Century Britain

(Oxford: Oxford University Press, 2011), 238 p, ISBN 978-0-1-958458-1

1 Samuel Alberti's Morbid Curiosities: Medical Museums in Nineteenth-Century Britain is a very recently published study which lifts the veil on the construction of medical museums in the nineteenth century. The book throws light on medical museums as part of nineteenth-century cultures of display and the development of a medical marketplace. Indeed, because they exhibited diseased body parts which were also circulated as commodities, medical museums offer good examples of the links between science and culture and the cultural construction of (medical) science. Alberti shows how the material construction and display of disease in the nineteenth century was part of the development of material culture, and highlights how exhibited parts were gradually dehumanised: since anatomists, such as the Hunter brothers, "render[ed] an intangible disease concept into a physical thing, to be studied, analysed, displayed, and compared with other objects" (6), they materialized disease.

2 Alberti looks at pathological collections and the development of pathological anatomy (especially in the first half of the century), as exemplified by the work of William (17181783) and John Hunter (1728-1793) in Britain or Marie François Xavier Bichat (17711802) and Théophile Laënnec (1781-1826) in France-works which influenced many anatomists (Chapter 2). Although pathology did not reach a professional critical mass in England until very late in the century (unlike in Germany, for instance, where pathologists following in the footsteps of Rudolph Virchow (1821-1902) held 
prestigious recognized positions), there was a gap between the collections that individual anatomists were constituting and the lack of a large professional community. Among the 100 pathological collections in the nineteenth century, Alberti mentions a few in London (those of the Hunter brothers, Joshua Brooke, Aston Key, Edward Grainger, etc.--with teaching hospitals such as St Bartholomew's or showmen playing a significant role too). He also looks at collections in Glasgow, Edinburgh, Dublin and Manchester. As he explains, anatomical collections often occupied liminal or interstitial spaces between the world of the home and the anatomy school (typical examples being the Hunters or Joseph Jordan collections). Gradually, proprietary medical schools, hospitals and royal colleges absorbed collections, and buildings were erected to host the collections. The organisation within the collections often juxtaposed the pathological and the normal, as Bichat advised, and even zoological specimens were to be found alongside the human fragments. Moreover, with the rise of ethnology, specimens of different human races (particularly skulls) were also exhibited. The study traces the elaboration of a dividual body throughout the century, so Chapter 3, on the material and museological implications of the movements of human remains and the mechanics of nineteenth-century acquisition, examines the fragmentation of the body and its commodification. Alberti explains that the reason why dissection was seen as the ultimate punishment for criminals is related to early Christian attitudes and the need for the body to remain complete for resurrection. The dismembering of the body and selling of parts partook therefore of the nineteenthcentury objectification of nature: "to anatomize was to atomize" (73). By focussing on the rise of medical museums, Alberti follows in the footsteps of studies such as Elizabeth Wanning Harries's The Unfinished Manner: Essays on the Fragment in the LateEighteenth Century (1994), Linda Nochlin's The Body in Pieces: The Fragment as a Metaphor of Modernity (1994) or D.A. Hillman and Carla Mazzio's (eds) The Body in Parts: Fantasies of Corporeality in Early Modern Europe (1997), which have explored the impact and significance of human fragments. The cultural appeal of remains, like ruins, explains the interest in and the legitimization of collections and exhibitions of human remains. Indeed, écorchés and waxes "were imbued with classical traditions" (72) (Hunter's "Smugglerius", posing like the Roman Dying Gaul, being a case in point). But Alberti goes a step further by highlighting how medical museums were anchored just as much, if not more, in industrial culture: morbid specimens provided by hospital wards, as exchangeable goods, were seen as equivalent to manufactured goods for consumption; the patient's identity was more often than not erased and subsumed under that of the anatomist or collector.

4 Chapter 4 then focusses on some of the technical aspects of organic preparations and the search by anatomists for methods that could last in perpetuity. Alberti relates how embalming, the cleaning of bones on skeletal mounts, the application of gelatine and glycerine, large-scale freezing, or the Kaiserling technique (a formaline-based process) were explained in method manuals. Furthermore, as the pathological collections generated pathological knowledge they helped produce "an atlas of disease" (126), as Alberti underlines in Chapter 5: the piecing together of human remains and the arrangement of specimens, backed up by models in wax (although British modellers were rare) or images on paper, enabled the construction of systems and the different classifications. 
5 Lastly, Chapter 6 turns to medical museum visitors and the importance of medical museums in medical training. Even though pathological specimens were used for educational purposes, their exhibition raised gender issues (the access of female visitors to medical collections being restricted). Moreover, the medical museum visit often involved olfactory, tactile and aural sensations in addition to visual sensations, demanding an increase in policing: whether the displays encouraged wonder or disgust - probably influencing, Alberti surmises, late-Victorian Gothic fiction-they typified how amusement and sympathy gradually supplanted education. Calling therefore for a regulation of the gaze, together with the removal of the most gruesome specimens, the "increased conditioning of the museum visit ... gave rise to the sanctity of the modern museum object-the museum effect-developed in response to the museum affect" (195).

6 This journey through the constitution of medical museums in the nineteenth century is a fascinating exploration of an under-researched aspect of the development of pathology: the representation of disease and the construction and definition of the body in Western culture. By showing how anatomical pathology was first and foremost based upon objects deeply rooted in nineteenth-century cultures of display, Alberti's book offers an original insight into the history of medicine seen through the lens of museology. His investigation will prove of interest to scholars and students specializing in nineteenth-century culture, the history of medicine and the history of the body and museology.

\section{INDEX}

Mots-clés: anatomie, corps humain, histoire de la médecine, musée de la médecine

Keywords: anatomy, the body, history of medicine, medical museums

\section{AUTHORS}

\section{LAURENCE TALAIRACH-VIELMAS}

Professeur

Université Toulouse 2 - Le Mirail

talairac@univ-tlse2.fr 